\title{
Relasi Kualitas Batubara dengan Lingkungan Pengendapan pada Pit South Pinang dan Sekitarnya, PT. Kaltim Prima Coal, Sangatta Utara, Kutai Timur, Kalimantan Timur
}

\author{
Givandi Aditama*, Henarno Pudjihardjo, Ahmad Syauqi Hidayatillah \\ Departemen Teknik Geologi UNDIP, Jl. Prof Soedharto, SH., Semarang
}

\begin{abstract}
Abstrak
Total sulfur adalah salah satu parameter untuk menentukan kualitas batubara, dan tinggi rendahnya nilai total sulfur salah satunya dipengaruhi oleh lingkungan pengendapan batuan pengapit serta batubara itu sendiri. Abu dalam batubara merupakan material pengotor yang tersisa setelah proses pembakaran, sehingga keterdapatan abu dapat menurunkan kualitas batubara. Penelitian ini dilaksanakan pada area Pit South Pinang dan sekitarnya yang tersusun dari Formasi Balikpapan.

Observasi lapangan serta Measuring Stratigraphy (MS) dilakukan untuk mengetahui kondisi geologi daerah penelitian. Properti batubara, yang diketahui berdasarkan hasil analisis proksimat dan ultimat dari sampel sumur bor, menjadi parameter yang dianalisis untuk menginterpretasikan lingkungan pengendapan batubara di daerah penelitian.

Dijumpai empat satuan litologi pada daerah penelitian dari yang tertua hingga yang termuda yaitu Satuan Batulempung Karbonan Sisipan Batugamping, Satuan Batulempung Sisipan BatupasirBatubara, Satuan Batupasir Sisipan Batulanau dan Dataran Aluvial. Berdasarkan data yang diperoleh di lapangan, dapat diinterpretasikan bahwa satuan pembawa batubara, yaitu Satuan Batulempung Sisipan Batupasir-Batubara terendapkan pada lingkungan Transitional Lower Delta Plain. Batubara pada daerah penelitian berdasarkan ASTM D388-99 diklasifikasikan sebagai High Volatile C Bituminous Coal. Berdasarkan hubungan antara kondisi geologi dengan nilai total sulfur dan abu yang terdapat pada Pit South Pinang, lingkungan pengendapan cukup berpengaruh terhadap nilai total sulfur dan abu, semakin besar pengaruh air laut, nilai total sulfur dan abu menjadi lebih tinggi.
\end{abstract}

Kata kunci: properti batubara, Formasi Balikpapan, total sulfur, total abu.

\begin{abstract}
Total sulfur is one of the parameters to determine the quality of coal that is dependable on the depositional environment. Ash in coal is the remaining impurity material after the combustion process, so ash dampness can decrease the quality of coal. The research was conducted in the area of Pit South Pinang and surrounding areas,

Field observations and Measuring Stratigraphy (MS) were conducted to determine the geological condition of the study area. The coal properties, which is known based on the results of the proximate and ultimate analyzes of the borehole samples, becomes the parameter analyzed to interpret the coal deposition environment in the study area.

Four units of lithology were found in the research area from the oldest to the youngest: the carbonaceous claystone with intercalated limestone, the claystone with intercalated sandstone-coal, the sandstone with intercalated siltstone, and the Alluvium. Based on the data obtained in the field, it can be interpreted that the coal-bearing unit, the claystone with intercalated sandstone-coal is deposited in the Transitional Lower Delta Plain environment. Based on ASTM D388-99, coal from the research area is classified as High Volatile C Bituminous Coal. The relationship between geological conditions and the total sulfur and ash values contained in the South Pinang Pit, shows that the total value of sulfur and ash are most likely caused by the marine environment.
\end{abstract}

Keyword: coal properties, Balikpapan Formation, total sulphur, total ash.

PENDAHULUAN

Pulau Kalimantan merupakan pulau dengan deposit batubara terbesar di Indonesia, khususnya Kalimantan Timur yang mencapai 47.063 juta ton (Anonim, 2015). Selain untuk kepentingan industri, kondisi

*) Korespondensi : givanditama@gmail.com 
batubara yang melimpah tersebut dapat dimanfaatkan untuk penelitian mengenai batubara itu sendiri, salah satunya adalah studi mengenai lingkungan pengendapan batubara. Dalam penelitian ini, akan dipaparkan mengenai kondisi geologi, sejarah pembentukan batubara dan pengaruhnya terhadap kualitas batubara pada daerah South Pinang dan sekitarnya, Sangatta Utara, Kabupaten Kutai Timur, Kalimantan Timur. Penelitian ini bertujuan untuk mengetahui pengaruh lingkungan pengendapan dan fasies batubara.

\section{Geologi Regional Daerah Penelitian}

Daerah Sangatta terletak di antara Delta Mahakam dan Tinggian Mangkalihat yang merupakan bagian dari Cekungan Kutai bagian utara. Peta Geologi Lembar Sangatta pada Gambar 1 (Sukardi dkk., 1995) menunjukkan urutan satuan litostratigrafi daerah Kutai Timur dengan urutan dari tua ke yang muda adalah : Pamaluan (Tmp) yang saling menjari dengan Bebuluh
(Tmbe), Pulau Balang (Tmpb), Maluwi (Tmma), Balikpapan (Tmbp), dan Kampungbaru (Tmpk), dan endapan aluvial (Qal).

Daerah penelitian sendiri tersusun dari Formasi Balikpapan dengan litologi batupasir, batulempung, lanau, tuf, dan batubara. Pada perselingan batupasir kuarsa, lempung dan lanau terbentuk struktur silang siur. Setempat mengandung sisipan batubara dengan ketebalan antara 20-40 cm. Lempung berwarna kelabu, getas, mengandung muskovit, bitumen dan oksida besi. Tebal formasi \pm 2000 meter, dengan lingkungan pengendapan muka daratan-delta. Formasi ini berumur Miosen Tengah - Miosen Akhir.

Analisis terhadap Formasi Balikpapan di daerah Sangatta menjelaskan bahwa sistem delta di Sangatta merupakan perkembangan delta tersendiri di bagian utara Cekungan Kutai dan terpisah dari sitem Delta Mahakam purba di bagian selatan (Snedden dkk, 1996).

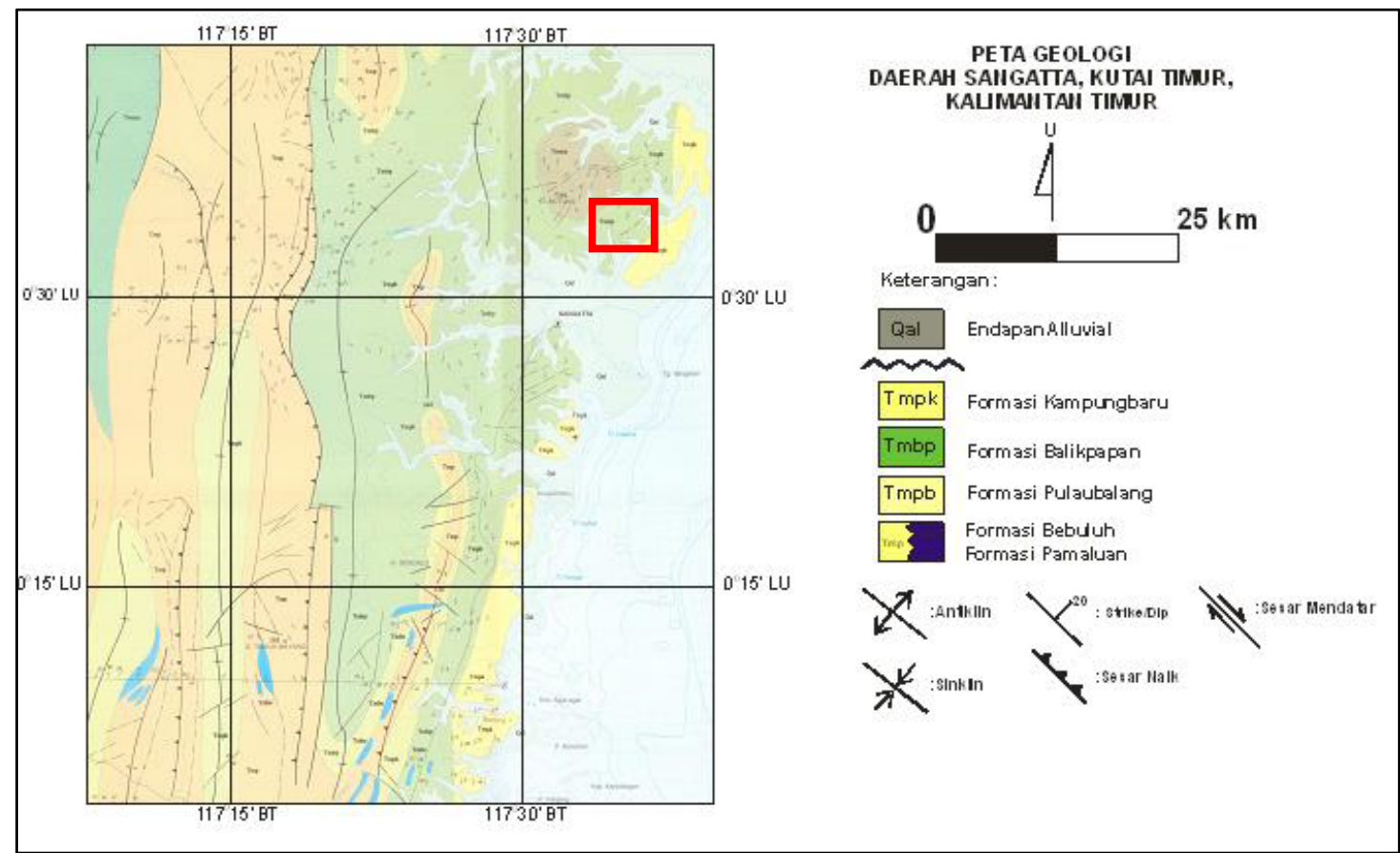

Gambar 1. Peta Geologi Regional lembar Sangatta (Sukardi dkk., 1995), daerah penelitian ditandai kotak merah.

Di daerah dijumpai tiga jenis sesar, yaitu sesar naik, sesar normal, dan sesar mendatar. Sesar naik diduga terjadi pada Miosen Akhir yang kemudian dipotong oleh sesar mendatar, sedangkan sesar turun terjadi pada Kala Pliosen (Supriatna dan Rustandi, 1995 dalam Resmawan, 2007). 


\section{METODOLOGI}

Pemetaan geologi pada daerah penelitian mencakup deskripsi litologi, serta pengukuran stratigrafi dan struktur geologi. Penelitian ini menggunakan data sekunder peta topografi week-31 daerah South Pinang dan sekitarnya, serta 226 titik sumur bor yang memiliki informasi log litologi dan batubara. Pada sumur dengan kode F memiliki data total moisture, inherent moisture, ash content, volatile matter, fixed carbon, insitu density, relative density, calorific value dan total sulphur.

\section{HASIL ANALISIS}

\section{Satuan Litologi Daerah Penelitian}

Daerah penelitian dapat dikelompokkan ke dalam empat satuan litologi, ditunjukkan dalam peta pada Gambar 2, dengan urutan dari tua ke muda, yaitu:

Satuan Batulempung Sisipan Batugamping Satuan ini didominasi oleh litologi berupa batulempung dan batulempung karbonan, dengan terdapat sisipan batupasir, pada bagian atas terdapat batugamping. Batulempung dalam satuan ini memiliki karakteristik warna abu-abu kehitaman, tebal 10-40 meter. Struktur sedimen yang dominan adalah masif dan wavy lamination-lenticular dimana batupasir berukuran butir pasir halus-sedang menyisip dengan bentuk seperti lensa. Keterdapatan batugamping pada satuan ini merupakan sisipan dengan ketebalan 2-3 meter pada bagian paling atas satuan ini.

\section{Satuan Batulempung Sisipan Batupasir dan Batubara}

Batulempung dalam satuan ini memiliki karakteristik warna abu-abu kehitaman, tebal 1-10 meter. Struktur sedimen yang dijumpai adalah masif dan beberapa dijumpai struktur wavy laminationlenticular dimana batupasir berukuran butir pasir halus-sedang menyisip dengan bentuk seperti lensa. Batulempung dalam satuan ini memiliki karakteristik warna abu-abu kehitaman, tebal 1-10 meter. Struktur sedimen yang dijumpai adalah masif dan beberapa dijumpai struktur laminasi bergelombang-melensa dengan lensa berupa batupasir berukuran butir pasir halus-sedang. Sisipan konkresi siderit dijumpai setempat, penanda diagenesis yang terjadi secara reduksi dalam air tawar pada lingkungan darat - transisi (Diessel, 1992).

Batubara dalam satuan ini memiliki karakteristik warna hitam mengilap. Cleat tersebut terisi oleh pirit dengan ukuran butir halus, warna coklat keemasan. Pirit tersebut merupakan sulfur epigenetik yang terbentuk setelah batubara terendapkan dan mengisi celah yang ada pada cleat. Batubara yang ada pada daerah penelitian dalam satuan ini, dengan urutan paling bawah menuju ke atas, terdiri dari seam JR, BE, E2, ML, L4, PR1, BN, B2 dan B2UR yang bersifat multiseam. Multiseam merupakan sifat endapan batubara yang terdiri atas beberapa seam yang tipis. Ketebalan batubara berkisar antara $50-300 \mathrm{~cm}$. Selain seam tersebut, terdapat pula lapisan-lapisan tipis batubara dengan tebal $20-40 \mathrm{~cm}$ yang berasosiasi dengan batulanau serpih. Berdasarkan karakteristik litologi, struktur sedimen dan pola yang cenderung mengkasar keatas (coarsening upward), mengindikasikan adanya pengaruh arus suspensi, traksi dan tidal, mengindikasikan bahwa satuan ini terendapkan pada lingkungan transitional lower delta plain (Horne dkk., 1978)

\section{Satuan Batupasir Sisipan Batulanau}

Satuan ini didominasi oleh litologi berupa batupasir, dengan terdapat sisipan batulanau, serpih dan konglomerat pasiran, serta batubara. Batupasir dalam satuan ini memiliki warna coklat kekuningan. Struktur sedimen yang dijumpai adalah graded bedding yang bagian bawah berupa batupasir konglomeratan dengan fragmen berupa kuarsa, litik dan feldspar, cross bedding-lamination. Pola sedimentasi cenderung mengkasar ke atas mengindikasikan adanya pengaruh arus traksi dan tidal seperti yang terjadi pada lingkungan transitional lower delta plain (Horne dkk., 1978). 


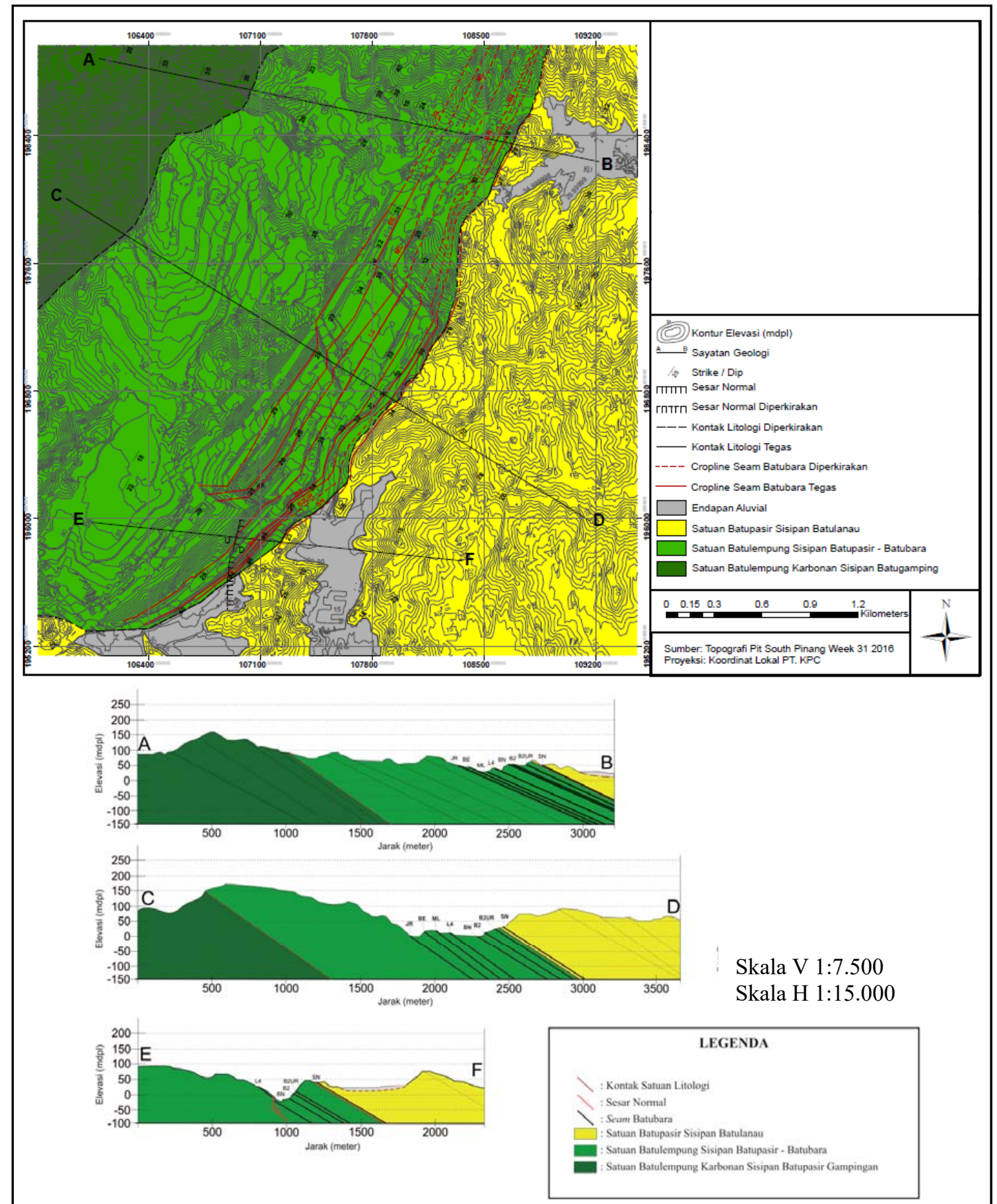

Gambar 2. Peta satuan litologi daerah penelitian dan penampang geologi dari sayatan pada peta.

\section{Endapan Aluvial}

Satuan ini tersusun atas endapan sedimen unconsolidated yang memiliki ukuran butir yang cenderung halus.

\section{Kualitas dan Peringkat Batubara Daerah Penelitian}

Seam JR merupakan seam dengan kedudukan paling bawah yang memiliki total abu $1,78 \%$ dan semakin bertambah menuju seam B2UR (Tabel 1, Gambar3). Calorific value justru menunjukkan penurunan nilai seiring dengan kenaikan kedudukan batubara. Penentuan peringkat batubara menggunakan klasifikasi ASTM 2004 dengan parameter Fixed Carbon, Volatile Matter, dan Calorific Value. Batubara di daerah penelitian memiliki nilai-nilai parameter yang diklasifikasikan sebagai high volatile $C$ bituminous. 
Tabel 1. Nilai Rata-rata Kualitas Batubara pada Sampel Pengeboran

\begin{tabular}{cccccccc}
\hline \multirow{2}{*}{ Seam } & $\begin{array}{c}\text { Total } \\
\text { Moisture }\end{array}$ & $\begin{array}{c}\text { Ash } \\
\text { Content }\end{array}$ & $\begin{array}{c}\text { Volatile } \\
\text { Matter }\end{array}$ & $\begin{array}{c}\text { Fixed } \\
\text { Carbon }\end{array}$ & Densitas & $\begin{array}{c}\text { Calorific } \\
\text { Value }\end{array}$ & Sulfur \\
\hline JR & 12.95 & 1.78 & 41.31 & 63.83 & 1.30 & 6.790 & 1.03 \\
BE & 13.78 & 2.52 & 39.97 & 46.93 & 1.30 & 6.627 & 1.83 \\
ML & 14.80 & 2.52 & 39.78 & 46.53 & 1.30 & 6.619 & 1.36 \\
L4 & 15.86 & 2.58 & 39.45 & 45.79 & 1.30 & 6.466 & 0.98 \\
BN & 15.28 & 4.16 & 39.29 & 44.92 & 1.31 & 6.410 & 2.03 \\
B2 & 16.02 & 2.40 & 39.46 & 45.62 & 1.30 & 6.502 & 0.92 \\
B2UR & 16.37 & 2.10 & 40.27 & 46.17 & 1.29 & 6.578 & 1.03 \\
\hline
\end{tabular}

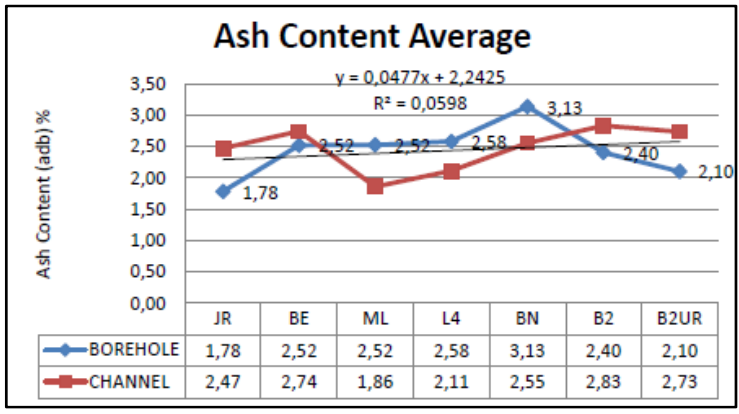

Gambar 3. Grafik nilai rata-rata abu dari seam paling bawah (JR) hingga seam paling atas (B2UR).

\section{PEMBAHASAN}

\section{Stratigrafi Daerah Penelitian}

Satuan Batulempung Karbonan Sisipan Batugamping merupakan satuan dengan umur paling tua pada daerah penelitian. Dalam skala regional, satuan ini dapat disebandingkan dalam Formasi Pamaluan (Gambar 4) yang berumur Miosen Awal (Sukardi, dkk., 1995). Satuan tersebut didominasi oleh batulempung dan batulempung karbonan dengan struktur sedimen lenticular-flaser dengan sisipan batupasir nonkarbonatan masif, ukuran butir pasir halus-sedang yang memiliki ketebalan 1-10 cm. Pada bagian atas terdapat batugamping bafflestone (Embry \& Klovan, 1971) dengan komposisi berupa koral terumbu. Karakteristik litologi yang ada pada satuan ini mengindikasikan bahwa sedimentasi dipengaruhi oleh arus tidal atau pasang-surut air laut, serta gelombang air laut yang dapat memecah fragmen terumbu, sehingga lingkungan pengendapan yang memungkinkan terendapkan satuan tersebut adalah lingkungan Intertidal flat pada neritik dangkal.

Satuan Batulempung Karbonan Sisipan Batugamping secara selaras terendapkan di atas Satuan Batulempung Sisipan Batupasir-
Batubara. Satuan ini secara regional dapat disebandingkan ke dalam Formasi Balikpapan yang berumur Miosen TengahAkhir (Sukardi, dkk., 1995) (Gambar 4). Satuan ini didominasi oleh batulempung dengan struktur masif dan beberapa tempat dijumpai struktur lenticular-flaser yang berasosiasi dengan sisipan batulanau serpih karbonan dan batubara. Endapan batupasir dengan struktur sedimen cross beddinglamination yang memiliki kecenderungan menghalus ke atas (fining upward) dengan kontak erosional (scour) sebagai endapan channel juga umum dijumpai, dan pada bagian atas semakin menebal. Berdasarkan karakteristik litologi tersebut, sedimentasi dipengaruhi oleh arus suspensi, tidal dan traksi, yang terendapkan pada lingkungan Transitional Lower Delta Plain (Horne dkk., 1978) dengan pengaruh fluviatil dan tidal.

Setelah Satuan Batulempung Sisipan Batupasir-Batubara terendapkan, secara selaras di atasnya terendapkan Satuan Batupasir Sisipan Batulanau. Kontak antara kedua satuan tersebut menunjukkan perubahan ukuran butir yang semakin mengkasar ke atas secara bertahap. Secara regional, satuan ini dapat disebandingkan dalam Formasi Balikpapan berumur Miosen Tengah-Akhir (Sukardi, dkk., 1995) (Gambar 4). Satuan ini dicirikan dengan litologi yang dominan berupa batupasir dan batupasir konglomeratan yang memiliki struktur sedimen cross bedding-lamination dengan pola fining upward yang bagian bawah berupa batupasir konglomeratan dan menghalus keatas dan semakin keatas semakin menebal, yang berasosiasi dengan sisipan batulanau, batulanau serpih karbonan serta batubara. Karakteristik litologi yang dijumpai mengindikasikan bahwa sedimentasi 
dipengaruhi oleh arus suspensi dan arus traksi, sehingga lingkungan yang paling mungkin mengendapkan satuan tersebut adalah lingkungan Transitional Lower Delta Plain (Horne, 1978) dengan pengaruh fluvial dan tidal.

\section{Relasi Kualitas Batubara Daerah Penelitian terhadap Lingkungan Pengendapan}

Kenaikan nilai total sulfur dan abu, umumnya berbanding lurus dengan lingkungan pengendapan yang semakin mendekati laut. Namun, berdasarkan data litostratigrafi yang diperoleh di lapangan, menunjukkan bahwa ada progradasi delta yang artinya terjadi pergerakan fasies delta kearah laut, sehingga semakin keatas semakin jauh dari muka air laut.

Anomali tersebut dapat disebabkan karena pada saat pengendapan gambut pada lingkungan rawa (swamp), air laut menerobos dan menggenangi permukaan rawa. Hal tersebut diperkuat dengan melimpahnya konkresi siderit yang menyisip pada batulempung yang mengindikasikan bahwa ada pengaruh air laut pada saat proses pengendapan batubara. Konkresi siderit (FeCO3) tersusun atas unsur besi yang berasal dari darat, kemudian terendapkan pada lingkungan yang mendukung aktivitas bikarbonat yaitu lingkungan transisi - laut. Penghilangan karbon dioksida (CO2) menyebabkan ion bikarbonat teruraikan, sehingga kehadiran siderit juga sering muncul dalam lingkungan pengendapan batubara. Semakin melimpah konkresi siderit maka lingkungan pengendapannya semakin mendekati laut.

\begin{tabular}{|c|c|c|c|c|c|c|c|c|}
\hline \multicolumn{3}{|c|}{$\begin{array}{l}\text { Stratigrafi Regional } \\
\quad \text { (Sukardi, dkk., 1995) }\end{array}$} & $\begin{array}{l}\text { Stratigrafi } \\
\text { Daerah } \\
\text { Penelitian }\end{array}$ & $\begin{array}{l}\text { Satuan } \\
\text { Litologi } \\
\text { (SSI, 1996) }\end{array}$ & Pemerian & Formasi & Umur & $\begin{array}{l}\text { Lingkungan } \\
\text { Pengendapan }\end{array}$ \\
\hline \multirow{5}{*}{ 兴 } & 壳 & Qa & & Endapan Aluvial & $\begin{array}{l}\text { Endapan rawa aluvial dengan fragmen } \\
\text { berbutir halus berupa pasir - lempung. }\end{array}$ & Aluvium & Holosen & Fluvial - Terrestrial \\
\hline & $\stackrel{\overline{0}}{\underline{\Xi}}$ & & & \multirow{3}{*}{$\begin{array}{c}\text { Satuan Batupasir } \\
\text { Sisipan Batulanau }\end{array}$} & \multirow{3}{*}{$\begin{array}{c}\text { Satuan ini tersusun atas litologi yang dominan } \\
\text { berupa batupasir dengan struktur masif, wavy } \\
\text { dan cross bedding-lamination dan batupasir } \\
\text { konglomeratan dengan struktur fining upward. } \\
\text { Terdapat sisipan berupa batulempung, } \\
\text { batulanau serpih dan batubara seam MD } \\
\text { dengan ketebalan } 1-3 \text { meter dan beberapa }\end{array}$} & \multirow{5}{*}{ 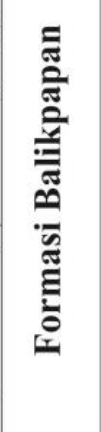 } & \multirow{5}{*}{ 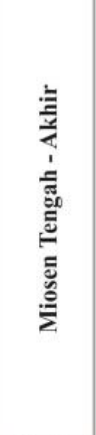 } & \multirow{5}{*}{$\begin{array}{l}\text { Transitional } \\
\text { Lower } \\
\text { Delta Plain } \\
\text { (Horne, 1978) }\end{array}$} \\
\hline & 空 & & & & & & & \\
\hline & $\frac{5}{2}$ & & & & & & & \\
\hline & $a$ & & & \multirow[b]{2}{*}{$\begin{array}{c}\text { Satuan } \\
\text { Batulempung } \\
\text { Sisipan Batupasir- } \\
\text { Batubara }\end{array}$} & \multirow{2}{*}{$\begin{array}{c}\text { Satuan ini tersusun atas litologi yang dominan } \\
\text { berupa batulempung nonkarbonatan dengan } \\
\text { struktur masif, lenticular dan flaser dengan } \\
\text { sisipan batupasir nonkarbonatan dengan } \\
\text { strukturu wavy-lamination dan cross } \\
\text { lamination, batulanau serpih dan seam } \\
\text { batubara JR, BE, ML, L4, BN, B2, B2UR dan } \\
\text { SN dengan ketebalan 1-3 meter. }\end{array}$} & & & \\
\hline \multirow{2}{*}{ 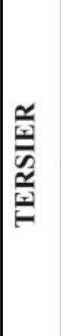 } & $\begin{array}{l}\text { 존 } \\
\frac{1}{0} \\
\frac{0}{3}\end{array}$ & Tmpk & 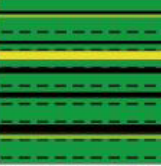 & & & & & \\
\hline & 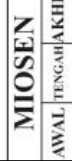 & 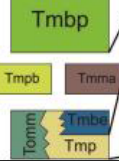 & & $\begin{array}{c}\text { Satuan } \\
\text { Batulempung } \\
\text { Karbonan Sisipan } \\
\text { Batugamping }\end{array}$ & \begin{tabular}{|} 
Satuan ini tersusun atas litologi yang dominan \\
berupa batulempung karbonan dengan \\
struktur masif, lenticular dan flaser dengan \\
sisipan perselingan batupasir masiff-flaser, \\
bagian atas berupa batugamping bafflestone \\
(Dunham, 1962).
\end{tabular} & 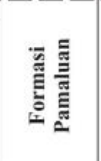 & 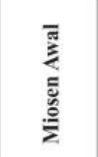 & $\begin{array}{c}\text { Intertidal } \\
\text { (Dairlymple, 1992) }\end{array}$ \\
\hline
\end{tabular}

Gambar 4. Kolom kesebandingan stratigrafi daerah Pit South Pinang dan Sekitarnya (tanpa skala)

(Sukardi dkk., 1995; Sandi Stratigrafi Indonesia, 1996)

\section{KESIMPULAN}

Urutan stratigrafi daerah penelitian, tua ke muda, adalah Satuan Batulempung Karbonan Sisipan Batugamping, kemudian secara selaras di atasnya terendapkan Satuan Batulempung Sisipan BatupasirBatubara, di atasnya terendapkan secara selaras Satuan Batupasir Sisipan Batulanau yang kemudian ditumpangi endapan aluvium secara tidak selaras.

Batubara yang terdapat pada daerah penelitian Pit South Pinang berada pada Satuan Batulempung Sisipan BatupasirBatubara dengan lingkungan pengendapan Transitional Lower Delta Plain (Horne dkk., 1978). 
Nilai rata-rata sulfur $(0,92 \%-2,03 \%)$ dan abu $(1,78 \%$ - 4,16\%) yang tinggi pada seam di daerah penelitian dapat disebabkan oleh lingkungan pengendapan batubara yang terkena pengaruh air laut pada saat proses pengendapan gambut, didukung dengan data stratigrafi yang ditemukan di lapangan dengan lingkungan Transitional Lower Delta Plain (Horne , 1978).

\section{UCAPAN TERIMA KASIH}

Penulis mengucapkan terima kasih kepada pihak PT. Kaltim Prima Coal yang telah memberikan izin pengambilan data pada area tambangnya untuk kepentingan penelitian ini. Terima kasih juga saya ucapkan kepada Bapak Aryo Susatyono dan Aloysius Prananto, serta semua yang membantu penulis selama melakukan pengambilan data di lapangan.

\section{DAFTAR PUSTAKA}

Anonim, 2015. Executive Summary: Pemutakhiran Data dan Neraca Sumber
Daya Energi. Badan Geologi, Kementerian Energi dan Sumberdaya Mineral, Pusat Sumber Daya Geologi, Bandung.

Diessel, C. F. 1992. Coal-Bearing Depositional Systems. Springer-Verlag, Australia.

Horne, J. C., Ferm, J. C., Caruccio, F. T., Baganz, B. P., 1978. Depositional Models in Coal Exploration and Mine Planning in Appalachian Region. AAPG Bulletin Vol. 62, hal. 2379-2411.

Sandi Stratigrafi Indonesia. 1996. Sandi Stratigrafi Indonesia. Jakarta: Ikatan Ahli Geologi Indonesia.

Resmawan, 2007. Analisis Variasi Kandungan Sulfur Pada Batubara Seam S di Daerah Palaran Kutai Kartanegara, Kalimantan Timur. Program Studi Rekayasa Pertambangan, ITB, Bandung.

Sukardi, N., Sikumbang, I., Umar, Sunaryo, R. 1995. Peta Geologi Lembar Sangatta, Kalimantan Timur skala 1:250.000. Pusat Penelitian Dan Pengembangan Geologi, Bandung. 